\title{
ANALISIS HUBUNG SINGKAT PADA GARDU INDUK 150/20 KV (STUDI KASUS DI GARDU INDUK GANDUL, CINERE)
}

\author{
${ }^{1}$ Cilvia Calnela, ${ }^{2}$ Suyitno, ${ }^{3}$ Imam Arif R. \\ 1,2,3 Pendidikan Teknik Elektro, Fakultas Teknik, Universitas Negeri Jakarta \\ 1,2,3 Email: cilviacalnela7@gmail.com ; suyitno@unj.ac.id ; imam_ar@unj.ac.id
}

\begin{abstract}
This study aims to determine the difference in short circuit current with manual calculation and ETAP 12.60 Simulation in to know the suitability of capacity circuit breaker Substasion 150/20 kV at Gandul. The used method is qualitative descriptive method. The subject that will be studied is short circuit on the substation 150/20 kV Gandul Cinere. The research was conducted by using is manual calculation and software ETAP 12.60 simulation. The results obtained is differences of the short circuit current is not significant between the manual calculation and software ETAP 12.60 simulation in three conditions include $0.572 \%$ for the conditions of short circuit fault of one phase to ground, $0.884 \%$ for the conditions of short circuit fault of phase to phase and last $0.884 \%$ for the short circuit fault of three phase. Furthermore, the result of the calculation of the short circuit current will be used as an indicator of a determinant of the suitability of the capacity circuit breaker substation 150/20 kV at Gandul, obtained that a comparison of the rating circuit breaker installed (existing) is great against the result of the election of the rating circuit breaker base on manual calculation. So it can be concluded that the circuit breaker beinstalled on the substation 150/20 KV at Gandul, has a capacity that suits your needs and still fit for use.
\end{abstract}

Keywords: Short Circuit Current, The Capacity of circuit breaker, software ETAP Power Station 12.60 Simulation.

\begin{abstract}
Abstrak
Penelitian ini bertujuan untuk mengetahui perbedaan besar arus hubung singkat antara perhitungan manual dan simulasi ETAP Power Station 12.6 serta untuk mengetahui kesesuaian kapasitas pemutus tenaga GI Gandul $150 / 20 \mathrm{kV}$. Metode yang digunakan adalah deskriptif kualitatif. Subjek pada penelitian ini adalah arus hubung singkat pada Gardu Induk 150/20 kV Gandul Cinere. Penelitian dilakukan menggunakan perhitungan manual dan simulasi software ETAP Power Station 12.6. Hasil penelitian diperoleh bahwa perbedaan hasil arus hubung singkat yang tidak signifikan antara perhitungan manual dan simulasi software ETAP Power Station 12.6 dalam tiga kondisi meliputi $0.572 \%$ untuk kondisi gangguan hubung singkat salah satu fasa ketanah, $0.884 \%$ untuk kondisi gangguan arus hubung singkat fasa ke fasa dan terakhir $0.884 \%$ untuk gangguan arus hubung singkat tiga fasa. Selanjutnya, hasil perhitungan arus hubung singkat tersebut akan digunakan sebagai indikator penentu kesesuaian kapasitas pemutus PMT (Circuit Breaker) GI Gandul 150/20 kV, diperoleh bahwa perbandingan rating pemutus PMT yang terpasang (existing) lebih besar terhadap hasil pemilihan rating pemutus PMT berdasarkan perhitungan manual. Sehingga dapat disimpulkan bahwa pemutus tenaga yang terpasang pada di GI Gandul 150/20 kV memiliki kapasitas yang sesuai dengan kebutuhan dan masih layak digunakan.
\end{abstract}

Kata kunci: Arus Hubung Singkat, Kapasitas pemutus tenaga (Circuit Breaker), Simulasi ETAP Power Station 12.60

\section{PENDAHULUAN}

Analisis gangguan hubung singkat adalah analisis yang mempelajari kontribusi arus gangguan hubung singkat yang mungkin mengalir pada setiap cabang didalam sistem tenaga listrik. Pada umumnya, analisis hubung singkat diakukan ketika sistem tenaga listrik baru akan dibuat atau dalam perancangan, bertujuan untuk mengetahui kapasitas yang dibutuhkan pada tiap komponen atau peralatan dalam suatu jaringan. Namun, analisis ini dapat dilakukan kembali pada sistem tenaga listrik yang telah ada dan biasanya dilakukan pada sistem tenaga listrik yang mengalami perubahan atau perkembangan berupa perubahan jaringan pada transmisi dan perkembangan sistem beban yang terpasang (Feeder atau penyulang) dan sebagainya.

Perubahan jaringan pada sistem tenaga listrik tersebut yang mengharuskan dilakukannya studi analisa hubung singkat kembali bertujuan untuk memastikan apakah komponen atau peralatan proteksi pada sistem tenaga listrik masih mampu meng-handle ketika terjadi gangguan arus hubung singkat.

Dalam penelitian ini, peneliti memilih lokasi yang telah mengalami perkembangan atau perubahan baik perubahan jaringan atau perkembangan sistem beban, peneliti memilih 
lokasi penelitian di Gardu Induk Gandul, Cinere, Jakarta selatan karena berdasarkan data yang diperoleh bahwa GI Gandul telah mengalami beberapa perubahan jaringan meliputi: bertambahnya sumber daya yaitu IBT 4, penambahan bay penghantar Pondok Indah I dan bay Pondok Indah II serta penambahan beban penyulang $20 \mathrm{kV}$ (feeder) hingga kini jumlah feeder yang merupakan pembebanan output di trafo 1, trafo 2, trafo 3 dan trafo 4 pada GI Gandul ialah sebanyak 62 penyulang (feeder).

Selain ditinjau dari perubahan jaringan dan penambahan atau pengurangan bay Penghantar dan penyulang tersebut, peneliti juga memperoleh data yang menyatakan bahwa GI Gandul $150 \mathrm{kV}$ mengalami gangguan beberapa kali yaitu berupa trip pada bulan Januari, Juni dan November 2017. Gangguan trip ini dapat terjadi dikarena oleh beberapa hal dan kemungkinan gangguan tersebut terjadi akibat perubahan jaringan yang terjadi pada Gardu Induk Gandul sehingga arus yang melewati setiap peralatan melebihi kapasitas yang ada.

Oleh karena itu, pentingnya dilakukan analisis gangguan hubung singkat untuk mengetahui besar arus maksimal yang akan melewati setiap peralatan. Kemudian menentukan kapasitas peralatan yang sesuai dengan kebutuhan, khususnya ialah Pemutus tenaga (Circuit Breaker) yang merupakan salah satu peralatan proteksi pada sistem tenaga listrik. dengan demikian peneliti dapat mengetahui bahwa peralatan yang terpasang pada GI Gandul apakah masih dapat menghandle ketika mengalami gangguan meskipun sistem jaringan atau sistem pembebanan pada GI Gandul telah mengalami perubahan.

Analisis ini dapat dilakukan dengan menggunakan metode analisis hubung singkat seimbang dan tidak seimbang atau komponen simetris. Dan untuk menghasilkan analisis yang cepat dan akurat maka digunakan sebuah software ETAP Power Station 12.60 sebagai program simulasi gangguan hubung singkat pada sistem tenaga listrik.

\section{METODE PENELITIAN}

Berdasarkan pada permasalahan yang diteliti, metode yang digunakan dalam penelitian ini adalah metode deskriptif kualitatif dengan mengumpulkan data real time berupa data logger yang merupakan kumpulan data real hasil pengukuran selama periode 1 tahun yang diperoleh dari sistem SCADA dan pemeliharaan yang dilakukan operator pihak GI Gandul setiap harinya. Selain itu, diperlukan data spesifikasi pada tiap peralatan sebagai data masukan dalam parameter-parameter yang dibutuhkan dalam simulasi software ETAP power station 12.60.

Penelitian ini dimaksudkan untuk mendapatkan kesimpulan mengenai kapasitas pemutus tenaga yang terpasang pada GI Gandul $150 / 20 \mathrm{kV}$, Hal ini guna mengetahui serta memastikan kesesuaian kapasitas pemutus tenaga apakah masih mampu menghandle ketika terjadi gangguan arus hubung singkat meskipun sistem jaringan pada GI Gandul 150/20 kV telah mengalami perubahan sistem jaringan dan perkembangan sistem beban.

\section{HASIL DAN PEMBAHASAN}

\section{Hasil Perhitungan Arus Hubung Singkat Dengan Menggunakan Simulasi ETAP Power Station 12.60}

Berdasarkan hasil penelitian diperoleh hasil perhitungan arus hubung singkat dengan menggunakan simulasi ETAP Power Station 12.60 ditunjukkan pada tabel 4.1:

Tabel 4.1. Hasil Perhitungan Arus Hubung Singkat Dengan Menggunakan Simulasi ETAP Power Station 12.60

\begin{tabular}{|c|c|c|}
\hline No. & $\begin{array}{l}\text { Jenis Arus } \\
\text { Hubung } \\
\text { Singkat }\end{array}$ & $\begin{array}{l}\text { Hasil Arus Hubung Singkat } \\
\text { Dengan Simulasi ETAP } \\
\text { Power Station } 12.60(\mathrm{kA})\end{array}$ \\
\hline \multirow[t]{3}{*}{1} & Salah Satu & \\
\hline & Fasa & 57.370 \\
\hline & Tanah & \\
\hline 2 & Fasa ke Fasa & 54.757 \\
\hline 3 & Tiga Fasa & 63.228 \\
\hline
\end{tabular}

\section{Hasil Perhitungan Arus Hubung Singkat Dengan Perhitungan Manual}

Hasil perhitungan arus hubung singkat dengan perhitungan manual merupakan hasil penjumlahan besar arus hubung singkat pada tiap bay (baris) penghantar yang terhubung terhadap busbar yang mengalami ganguan.

Bay yang terhubung pada busbar 1 dan 2 yang mengalami gangguan meliputi bay IBT 1, IBT2, IBT3, IBT4, Trafo 1, Trafo 2, Trafo 3, Trafo 4, Transmisi Line GI Kemang 1 dan 2, Transmisi Line GI Pondok Indah 1 dan 2, Transmisi Line GI Petukangan 1 dan 2, Transmisi Line GI Serpong 1 dan 2. 
Berikut ini hasil arus hubung singkat dengan perhitungan manual ditunjukkan pada tabel 4.2 sampai dengan tabel 4.4 .

Tabel 4.2. Hasil Perhitungan Manual Arus Hubung Singkat Salah Satu Fasa Ke Tanah

\begin{tabular}{llc}
\hline No. & $\begin{array}{c}\text { Nama bay (Baris) } \\
\text { Penghantar }\end{array}$ & $\begin{array}{c}\text { Arus Hubung } \\
\text { Singkat Salah Satu } \\
\text { Fasa ke Tanah } \\
\left(I_{S C ~ L-G}\right)\end{array}$ \\
\hline 1 & IBT 1 & 10.84442394 \\
2 & IBT 2 & 10.7836588 \\
3 & IBT 3 & 10.599540585 \\
4 & IBT 4 & 10.94931153 \\
5 & Trafo 1 & 0.457174979 \\
6 & Trafo 2 & 0.467588545 \\
7 & Trafo 3 & 0.458656872 \\
8 & Trafo 4 & 0.4559417224 \\
9 & TL Kemang 1 & 1.60951281757 \\
10 & TL Kemang 2 & 1.60951281757 \\
11 & TL Pondok Indah 1 & 1.60908480296 \\
12 & TL Pondok Indah 2 & 1.60908480296 \\
13 & TL Petukangan 1 & 1.43941953558 \\
14 & TL Petukangan 2 & 1.43941953558 \\
15 & TL Serpong 1 & 1.51878707194 \\
16 & TL Serpong 2 & 1.51878707194 \\
\hline \multicolumn{2}{c}{ Total Akhir } & $\mathbf{5 7 . 3 6 9 9 0 5 4 3}$ \\
\hline
\end{tabular}

Tabel 4.3 Hasil Perhitungan Manual Arus Hubung Singkat Fasa Ke Fasa

\begin{tabular}{llc}
\hline No. & $\begin{array}{c}\text { Nama bay (Baris) } \\
\text { Penghantar }\end{array}$ & $\begin{array}{c}\text { Arus Hubung } \\
\text { Singkat Fasa Ke } \\
\text { Fasa } \\
\left(I_{S C L-L}\right)\end{array}$ \\
\hline 1 & IBT 1 & 9.093546064 \\
2 & IBT 2 & 9.044199756 \\
3 & IBT 3 & 8.8945573362 \\
4 & IBT 4 & 9.178682169 \\
5 & Trafo 1 & 0.552055227 \\
6 & Trafo 2 & 0.562536328 \\
7 & Trafo 3 & 0.553582017 \\
8 & Trafo 4 & 0.554349212 \\
9 & TL Kemang 1 & 2.11914191 \\
10 & TL Kemang 2 & 2.11914191 \\
11 & TL Pondok Indah 1 & 2.11916501426 \\
12 & TL Pondok Indah 2 & 2.11916501426 \\
13 & TL Petukangan 1 & 1.91355585056 \\
14 & TL Petukangan 2 & 1.91355585056 \\
15 & TL Serpong 1 & 2.01008697147 \\
16 & TL Serpong 2 & 2.01008697147 \\
\hline \multicolumn{3}{c}{ Total Akhir } \\
\hline
\end{tabular}

Tabel 4.4 Hasil Perhitungan Manual Arus Hubung Singkat Tiga Fasa

\begin{tabular}{ccc}
\hline No. & $\begin{array}{c}\text { Nama bay (Baris) } \\
\text { Penghantar }\end{array}$ & $\begin{array}{c}\text { Arus Hubung } \\
\text { Singkat Tiga } \\
\text { Fasa } \\
\left(I_{S C L-L-L}\right)\end{array}$ \\
\hline 1 & IBT 1 & 10.50032254 \\
2 & IBT 2 & 10.44334233
\end{tabular}

\begin{tabular}{lll}
\hline 3 & IBT 3 & 10.27056865 \\
4 & IBT 4 & 10.59862924 \\
5 & Trafo 1 & 0.637458469 \\
6 & Trafo 2 & 0.649561001 \\
7 & Trafo 3 & 0.639221455 \\
8 & Trafo 4 & 0.640107335 \\
9 & TL Kemang 1 & 2.44697430352 \\
10 & TL Kemang 2 & 2.44697430352 \\
11 & TL Pondok Indah 1 & 2.44700098289 \\
12 & TL Pondok Indah 2 & 2.44700098289 \\
13 & TL Petukangan 1 & 2.20958397074 \\
14 & TL Petukangan 2 & 2.20958397074 \\
15 & TL Serpong 1 & 2.32104850815 \\
16 & TL Serpong 2 & 2.32104850815 \\
\hline \multicolumn{2}{c}{ Total Akhir } & $\mathbf{6 3 . 2 2 8 4 2 6 5 5}$ \\
\hline
\end{tabular}

\section{Perbandingan Hasil Arus Hubung Singkat} Pada Busbar 1 dan 2150 KV Dengan Perhitungan Manual dan Simulasi ETAP 12.6

Hasil perhitungan manual arus hubung singkat pada busbar 1 dan 2 akan dibandingkan dengan hasil simuasi dengan menggunakan ETAP 12.6. Untuk hasilnya dapat dilihat pada tabel 4.5 sampai dengan tabel 4.7.

Tabel 4.5 Perbandingan Hasil Perhitungan Arus Hubung Singkat Salah Satu Fasa Ke Tanah Dengan Perhitungan Manual dan Simulasi ETAP Power Station 12.60

\begin{tabular}{|c|c|c|c|}
\hline $\begin{array}{c}\text { Nama Bay (Baris) } \\
\text { Penghantar }\end{array}$ & $\begin{array}{c}\text { Hitung } \\
\text { Manual }\end{array}$ & $\begin{array}{c}\text { Hasil } \\
\text { ETAP }\end{array}$ & Selisih \\
\hline IBT 1 & 10.844 & 10.884 & -0.040 \\
\hline IBT 2 & 10.784 & 10.807 & -0.023 \\
\hline IBT 3 & 10.600 & 10.576 & 0.024 \\
\hline IBT 4 & 10.949 & 11.017 & -0.068 \\
\hline Trafo 1 & 0.457 & 0.461 & -0.004 \\
\hline Trafo 2 & 0.468 & 0.471 & -0.003 \\
\hline Trafo 3 & 0.459 & 0.465 & -0.006 \\
\hline Trafo 4 & 0.456 & 0.456 & 0.000 \\
\hline TL Kemang 1 & 1.610 & 1.558 & 0.0515 \\
\hline TL Kemang 2 & 1.610 & 1.558 & 0.0515 \\
\hline TL Pond. Indah 1 & 1.609 & 1.474 & 0.135 \\
\hline TL Pond. Indah 2 & 1.609 & 1.474 & 0.135 \\
\hline TL Petukangan 1 & 1.439 & 1.45 & -0.011 \\
\hline TL Petukangan 2 & 1.439 & 1.45 & -0.011 \\
\hline TL Serpong 1 & 1.519 & 1.532 & -0.013 \\
\hline TL Serpong 2 & 1.519 & 1.532 & -0.013 \\
\hline $\begin{array}{c}\text { Total Akhir } \\
\left(I_{S C L-G}\right)\end{array}$ & $\mathbf{5 7 . 3 7 0}$ & $\mathbf{5 7 . 0 4 2}$ & 0.328 \\
\hline
\end{tabular}

Tabel 4.6 Perbandingan Hasil Perhitungan Arus Hubung Singkat Fasa Ke Fasa Dengan Perhitungan Manual dan Simulasi ETAP Power Station 12.60

\begin{tabular}{lccc}
\hline $\begin{array}{c}\text { Nama Bay (Baris) } \\
\text { Penghantar }\end{array}$ & $\begin{array}{c}\text { Hitung } \\
\text { Manual }\end{array}$ & $\begin{array}{c}\text { Hasil } \\
\text { ETAP }\end{array}$ & Selisih \\
\cline { 2 - 4 } & $(\mathrm{kA})$ & $(\mathrm{kA})$ & $(\mathrm{kA})$ \\
\hline IBT 1 & 9.094 & 9.036 & 0.058 \\
IBT 2 & 9.044 & 8.975 & 0.069 \\
IBT 3 & 8.895 & 8.791 & 0.104 \\
IBT 4 & 9.179 & 9.142 & 0.037
\end{tabular}




\begin{tabular}{|c|c|c|c|}
\hline Trafo 1 & 0.552 & 0.543 & 0.009 \\
\hline Trafo 2 & 0.563 & 0.605 & -0.042 \\
\hline Trafo 3 & 0.554 & 0.596 & -0.042 \\
\hline Trafo 4 & 0.554 & 0.582 & -0.028 \\
\hline TL Kemang 1 & 2.119 & 2.073 & 0.046 \\
\hline TL Kemang 2 & 2.119 & 2.073 & 0.046 \\
\hline TL Pond. Indah 1 & 2.119 & 1.942 & 0.177 \\
\hline TL Pond. Indah 2 & 2.119 & 1.942 & 0.177 \\
\hline TL Petukangan1 & 1.914 & 1.956 & -0.042 \\
\hline TL Petukangan 2 & 1.914 & 1.956 & -0.042 \\
\hline TL Serpong 1 & 2.010 & 2.036 & -0.026 \\
\hline TL Serpong 2 & 2.010 & 2.036 & -0.026 \\
\hline $\begin{array}{c}\text { Total Akhir } \\
\left(I_{S C L-L}\right)\end{array}$ & 54.757 & 54.273 & 0.484 \\
\hline
\end{tabular}

Tabel 4.7 Perbandingan Hasil Perhitungan Arus Hubung Singkat Tiga Fasa Dengan Perhitungan Manual dan Simulasi ETAP Power Station 12.60

\begin{tabular}{lccc}
\hline \multirow{2}{*}{$\begin{array}{c}\text { Nama Bay (Baris) } \\
\text { Penghantar }\end{array}$} & $\begin{array}{c}\text { Hitung } \\
\text { Manual }\end{array}$ & $\begin{array}{c}\text { Hasil } \\
\text { ETAP }\end{array}$ & \multirow{2}{*}{ Selisih } \\
\cline { 2 - 4 } & $(\mathrm{kA})$ & $(\mathrm{kA})$ & $(\mathrm{kA})$ \\
\hline IBT 1 & 10.500 & 10.434 & 0.066 \\
IBT 2 & 10.443 & 10.363 & 0.080 \\
IBT 3 & 10.271 & 10.151 & 0.120 \\
IBT 4 & 10.599 & 10.556 & 0.043 \\
Trafo 1 & 0.637 & 0.627 & 0.010 \\
Trafo 2 & 0.650 & 0.699 & -0.049 \\
Trafo 3 & 0.639 & 0.688 & -0.049 \\
Trafo 4 & 0.640 & 0.672 & -0.032 \\
TL Kemang 1 & 2.447 & 2.393 & 0.054 \\
TL Kemang 2 & 2.447 & 2.393 & 0.054 \\
TL Pond. Indah 1 & 2.447 & 2.243 & 0.204 \\
TL Pond. Indah 2 & 2.447 & 2.243 & 0.204 \\
TL Petukangan 1 & 2.210 & 2.26 & 0.050 \\
TL Petukangan 2 & 2.210 & 2.26 & 0.050 \\
TL Serpong 1 & 2.321 & 2.352 & 0.031 \\
TL Serpong 2 & 2.321 & 2.352 & 0.031 \\
\hline$\quad$ Total Akhir & $\mathbf{6 3 . 2 2 8}$ & $\mathbf{6 2 . 6 6 9}$ & $\mathbf{0 . 5 5 9}$ \\
\hline (I $\boldsymbol{S C}$ L-L $\boldsymbol{L}$ ) & & &
\end{tabular}

Berdasarkan ketiga tabel diatas yaitu tabel 4.5 . sampai dengan tabel 4.7, maka diperoleh hasil selisih perhitungan arus hubung singkat dengan perhitungan manual dan simulasi ETAP secara keseluruhan baik dalam bentuk satuan kA maupun persentase yang ditunjukkan pada tabel 4.8:

Tabel 4.8 Persentase Hasil Perbandingan Arus Hubung Singkat Antara Hitungan Manual dan Simulasi ETAP (Electric Transient and Program) Power Station 12.60 Pada Busbar 1 atau $2150 \mathrm{kV}$

\begin{tabular}{|c|c|c|c|c|}
\hline \multirow{3}{*}{$\begin{array}{c}\text { Jenis } \\
\text { Arus } \\
\text { Hubung } \\
\text { Singkat }\end{array}$} & \multicolumn{2}{|c|}{$\begin{array}{c}\text { Metode } \\
\text { Perhitungan }\end{array}$} & \multirow{2}{*}{\multicolumn{2}{|c|}{ Selisih }} \\
\hline & $\begin{array}{c}\text { Hitungan } \\
\text { Manual }\end{array}$ & $\begin{array}{c}\text { Simulasi } \\
\text { ETAP }\end{array}$ & & \\
\hline & (kA) & (kA) & (kA) & $(\%)$ \\
\hline $\begin{array}{l}1 \text { Fasa Ke } \\
\text { Tanah }\end{array}$ & 57.370 & 57.042 & 0.328 & $\begin{array}{r}0.57 \\
2\end{array}$ \\
\hline
\end{tabular}

\begin{tabular}{llllr}
\hline Fasa Ke & 54.757 & 54.273 & 0.484 & 0.88 \\
Fasa & & & & 4 \\
Tiga Fasa & 63.228 & 62.669 & 0.559 & 0.88 \\
\end{tabular}

Berdasarkan tabel 4.8. diketahui selisih hasil perhitungan arus hubung singkat meliputi tiga kondisi (L-G), (L-L) dan (L-L-L) dengan perhitungan manual dan simulasi ETAP Power Station 12.60 secara keseluruhan baik dalam bentuk satuan kA maupun persentase.

Dalam tabel 4.8. diperoleh besar arus hubung singkat salah satu fasa ke tanah pada busbar 1 atau 2 yang menghasilkan perhitungan manual sebesar $57.370 \mathrm{kA}$ dan $57.042 \mathrm{kA}$ dengan simulasi ETAP 12.6. Sehingga didapati perbedaan besar arus hubung singkat salah satu fasa ke tanah antara perhitungan manual dan simulasi ETAP Power Station 12.60 sebesar $0.328 \mathrm{kA}$ dan dalam persentase ialah $0.572 \%$.

Kemudian untuk hasil arus hubung singkat fasa ke fasa pada busbar 1 atau 2 menghasilkan perhitungan manual sebesar $54.757 \mathrm{kA}$ dan 54.273 kA dengan simulasi ETAP 12.6. Sehingga didapati perbedaan besar arus hubung singkat fasa ke fasa antara perhitungan manual dan simulasi ETAP Power Station 12.60 sebesar 0.484 kA dan dalam persentase ialah $0.884 \%$.

Terakhir, hasil arus hubung singkat tiga fasa pada busbar 1 dan 2 sebesar $63.228 \mathrm{kA}$ dengan perhitungan manual dan $62.669 \mathrm{kA}$ dengan simulasi ETAP 12.6. Sehingga didapati perbedaan besar arus hubung singkat tiga fasa antara perhitungan manual dan simulasi ETAP Power Station 12.60 sebesar $0.559 \mathrm{kA}$ dan dalam persentase ialah $0.884 \%$.

Berdasarkan penjabaran hasil nilai arus hubung singkat tersebut, dapat dilihat bahwa hasil perhitungan arus hubung singkat dengan perhitungan manual lebih besar dibandingkan hasil perhitungan arus hubung singkat dengan menggunakan simulasi ETAP Power Station 12.60. Perbedaan hasil perhitungan arus hubung singkat antara perhitungan manual dan simulasi ETAP Power Station 12.60 tersebut disebabkan pada simulasi ETAP Power Station 12.60 menggunakan pembulatan angka desimal sebesar 3 digit dibelakang koma dan perhitungan manual menggunakan 8 sampai 9 digit dibelakang koma.

Perbedaan perhitungan baik dalam satuan kA maupun persentase yang tidak signifikan, sehingga bisa dijadikan referensi PLN. 


\section{Penentuan Kapasitas Pemutus Tenaga}

Dengan diperolehnya nilai arus hubung singkat maksimum yang diperoleh dari penjumlahan seluruh arus hubung singkat pada tiap Bay Penghantar, maka kapasitas pemutus Circuit Breaker dapat ditentukan dengan perhitungan yang dirincikan kedalam tabel 4.9

Tabel 4.9. Hasil Perhitungan Kapasitas Pemutus Tenaga PMT $150 \mathrm{kV}$ Pada Gardu Induk Gandul

\begin{tabular}{|c|c|c|c|}
\hline \multirow{4}{*}{ No } & \multirow{4}{*}{ Bay Penghantar } & $\begin{array}{c}\text { Arus } \\
\text { Gangguan } \\
\text { Maksimum }\end{array}$ & $\begin{array}{c}\text { Kapasitas } \\
\text { Pemutus } \\
\text { Tenaga }\end{array}$ \\
\hline & & $\left(I_{S C L}-L-L\right)$ & \\
\hline & & $\begin{array}{c}\text { Perhitungan } \\
\text { Manual }\end{array}$ & $\left(I_{S C L-L-L}\right) x 1.6$ \\
\hline & & $(\mathrm{kA})$ & $(\mathrm{kA})$ \\
\hline 1 & IBT 1 & 10.5 & 16.800 \\
\hline 2 & IBT 2 & 10.443 & 16.709 \\
\hline 3 & IBT 3 & 10.271 & 16.434 \\
\hline 4 & IBT 4 & 10.599 & 16.958 \\
\hline 5 & Trafo 1 & 0.637 & 1.019 \\
\hline 6 & Trafo 2 & 0.65 & 1.040 \\
\hline 7 & Trafo 3 & 0.639 & 1.022 \\
\hline 8 & Trafo 4 & 0.64 & 1.024 \\
\hline 9 & TL Kemang 1 & 2.447 & 3.915 \\
\hline 10 & TL Kemang 2 & 2.447 & 3.915 \\
\hline 11 & TL Pond. Indah 1 & 2.447 & 3.915 \\
\hline 12 & TL Pond. Indah 2 & 2.447 & 3.915 \\
\hline 13 & TL Petukangan 1 & 2.21 & 3.536 \\
\hline 14 & TL Petukangan 2 & 2.21 & 3.536 \\
\hline 15 & TL Serpong 1 & 2.321 & 3.714 \\
\hline 16 & TL Serpong 2 & 2.321 & 3.714 \\
\hline
\end{tabular}

Rating PMT dipasaran dengan tegangan $150 \mathrm{kV}$ meliputi $20 \mathrm{kA}, 25 \mathrm{kA}, 35 \mathrm{kA}$ dan $40 \mathrm{kA}$. Berdasarkan rating PMT dipasaran dan dengan memperhatikan kapasitas pemutus hasil perhitung manual dengan nilai paling besar ialah $16.958 \mathrm{kA}$ dapat dilihat pada tabel 4.9, maka dalam penelitian ini dipilih PMT dengan rating $20 \mathrm{kA}$ sebagai rating pemutus tenaga berdasarkan hasil perhitungan manual ditunjukkan pada tabel 4.10.

Tabel 4.10 Pemilihan Rating Pemutus Tenaga Berdasarkan Hasil Perhitungan Manual

\begin{tabular}{lcc}
\hline Bay Penghantar & $\begin{array}{c}\text { Kapasitas } \\
\text { Pemutus } \\
\text { Tenaga }\end{array}$ & $\begin{array}{c}\text { Rating PMT } \\
\text { Berdasarkan Hasil } \\
\text { Perhitungan Dengan } \\
\text { Melihat Rating } \\
\text { PMT di Pasaran }\end{array}$ \\
\cline { 2 - 3 } & $(\mathrm{kA})$ & $(\mathrm{kA})$ \\
\hline IBT 1 & 16.800 & 20 \\
IBT 2 & 16.709 & 20 \\
IBT 3 & 16.434 & 20 \\
IBT 4 & 16.958 & 20 \\
Trafo 1 & 1.019 & 20 \\
Trafo 2 & 1.040 & 20 \\
Trafo 3 & 1.022 & 20 \\
Trafo 4 & 1.024 & 20 \\
TL Kemang 1 & 3.915 & 20 \\
TL Kemang 2 & 3.915 & 20 \\
TL Pond. Indah 1 & 3.915 & 20 \\
\hline
\end{tabular}

\begin{tabular}{lll}
\hline TL Pond. Indah 2 & 3.915 & 20 \\
TL Petukangan 1 & 3.536 & 20 \\
TL Petukangan 2 & 3.536 & 20 \\
TL Serpong 1 & 3.714 & 20 \\
TL Serpong 2 & 3.714 & 20 \\
\hline
\end{tabular}

\section{Kesesuaian Kapasitas Pemutus Tenaga Yang Terpasang (existing) Pada Gardu Induk Gandul 150 KV}

Kesesuaian kapasitas pemutus tenaga pada GI gandul $150 \mathrm{kV}$ ialah dengan membandingkan rating PMT yang terpasang (exisiting) dengan perhitungan manual. Sehingga diperoleh kondisi kesesuaian kapasitas pemutus tenaga yang terpasang di GI Gandul pada tabel 4.11:

Tabel 4.11. Perbandingan Rating Pemutus PMT Existing di GI Gandul dengan Hasil Perhitungan Manual

\begin{tabular}{lccc}
\hline Nama Pemutus & $\begin{array}{c}\text { Rating } \\
\text { Pemutus } \\
\text { PMT Hasil } \\
\text { Perhitungan }\end{array}$ & $\begin{array}{c}\text { Rating } \\
\text { Pemutus } \\
\text { PMT } \\
\text { Terpasang } \\
\text { (Existing) }\end{array}$ & $\begin{array}{c}\text { Kondisi } \\
\text { Kapasitas } \\
\text { Pemutus PMT } \\
\text { GI Gandul } \\
\text { 150/20 } \boldsymbol{k} \boldsymbol{V}\end{array}$ \\
\cline { 2 - 4 } & $\mathbf{( k A )}$ & $\mathbf{( k A )}$ & $\begin{array}{c}\text { Sesuai/ Tidak } \\
\text { Sesuai }\end{array}$ \\
\hline IBT 1 & 20 & 63 & Sesuai \\
IBT 2 & 20 & 50 & Sesuai \\
IBT 3 & 20 & 63 & Sesuai \\
IBT 4 & 20 & 50 & Sesuai \\
Trafo 1 & 20 & 50 & Sesuai \\
Trafo 2 & 20 & 50 & Sesuai \\
Trafo 3 & 20 & 40 & Sesuai \\
Trafo 4 & 20 & 40 & Sesuai \\
TL Kemang 1 & 20 & 50 & Sesuai \\
TL Kemang 2 & 20 & 63 & Sesuai \\
TL Pd. Indah 1 & 20 & 63 & Sesuai \\
TL Pd.Indah 2 & 20 & 63 & Sesuai \\
TL Petukangan1 & 20 & 63 & Sesuai \\
TL Petukangan 2 & 20 & 63 & Sesuai \\
TL Serpong 1 & 20 & 63 & Sesuai \\
TL Serpong 2 & 20 & 63 & Sesuai \\
\hline
\end{tabular}

Dengan mengamati tabel 4.11 mengenai perbandingan antara rating pemutus tenaga (PMT) yang terpasang di GI Gandul Cinere terhadap hasil pemilihan rating pemutus tenaga (PMT) hasil perhitungan manual, diperoleh bahwa rating pemutus tenaga (PMT) yang terpasang di GI Gandul cinere lebih besar dari rating pemutus tenaga (PMT) berdasarkan hasil perhitungan.

Sehingga dapat disimpulkan bahwa kapasitas pemutus tenaga (PMT) yang terpasang di GI Gandul 150 kV Cinere, sesuai dan layak digunakan sebagai pemutus tenaga meskipun pada GI Gandul $150 \mathrm{kV}$ telah mengalami beberapa perkembangan dan perubahan sistem jaringan tenaga listrik meliputi penambahan sumber daya yaitu IBT $4(500 / 150 \mathrm{kV})$, 
penambahan sistem jaringan tranmisi line Pondok Indah dan bertambahnya penyulang hingga kini mencapai 62 feeder.

\section{KESIMPULAN DAN SARAN \\ Kesimpulan}

Dari hasil pembahasan tentang tentang studi hubung singkat pada sistem tenaga listrik PT.PLN (Persero) P3B Gandul Cinere khususnya GI Gandul sisi $150 \mathrm{kV}$ dapat diambil beberapa kesimpulan sebagai berikut :

1. Hasil selisih perhitungan arus hubung singkat antara perhitungan manual dengan hasil simulasi ETAP Power Station 12.6 tidak terlampau jauh yaitu kurang dari $1 \%$ pada tiap jenis hubung singkat meliputi $0.572 \%$ untuk selisih nilai arus gangguan hubung singkat salah satu fasa ke tanah $\left(I_{S c L-G}\right), 0.884 \%$ untuk selisih nilai arus gangguan hubung singkat dua fasa $\left(I_{S c L-L}\right)$ dan terakhir $0.884 \%$ untuk selisih nilai arus ganguan hubung singkat tiga fasa $\left(I_{S C L-L-L}\right)$. Hal ini menunjukkan bahwa simulasi ETAP Power Station 12.6 valid dan perhitungan yang dilakukan telah benar, sehingga dapat dijadikan referensi bagi PLN.

2. Berdasarkan nilai arus gangguan hubung singkat tiga fasa $\left(I_{S C L-L-L}\right)$ pada busbar 150 $\mathrm{kV}$ maka dapat ditentukan kapasitas pemutus PMT pada tiap bay sebagai berikut:

a. Kapasitas pemutus tenaga PMT sisi $150 \mathrm{kV}$ pada bay (baris) trafo IBT 1 sebesar 16.800 $\mathrm{kA}$ dengan pemilihan rating PMT yang tersedia dipasaran sebesar $20 \mathrm{kA}$

b. Kapasitas pemutus tenaga PMT sisi $150 \mathrm{kV}$ pada bay (baris) trafo IBT 2 sebesar 16.709 $\mathrm{kA}$ dengan pemilihan rating PMT yang tersedia dipasaran sebesar $20 \mathrm{kA}$

c. Kapasitas pemutus tenaga PMT sisi $150 \mathrm{kV}$ pada bay (baris) trafo IBT 3 sebesar 16.434 $\mathrm{kA}$ dengan pemilihan rating PMT yang tersedia dipasaran sebesar $20 \mathrm{kA}$

d. Kapasitas pemutus tenaga PMT sisi $150 \mathrm{kV}$ pada bay (baris) trafo IBT 4 sebesar 16.958 $\mathrm{kA}$ dengan pemilihan rating PMT yang tersedia dipasaran sebesar $20 \mathrm{kA}$

e. Kapasitas pemutus tenaga PMT sisi $150 \mathrm{kV}$ pada bay (baris) trafo daya 1 sebesar 1.019 $\mathrm{kA}$ dengan pemilihan rating PMT yang tersedia dipasaran sebesar $20 \mathrm{kA}$

f. Kapasitas pemutus tenaga PMT sisi $150 \mathrm{kV}$ pada bay (baris) trafo daya 2 sebesar 1.040
kA dengan pemilihan rating PMT yang tersedia dipasaran sebesar $20 \mathrm{kA}$

g. Kapasitas pemutus tenaga PMT sisi $150 \mathrm{kV}$ pada bay (baris) trafo daya 3 sebesar 1.022 $\mathrm{kA}$ dengan pemilihan rating PMT yang tersedia dipasaran sebesar $20 \mathrm{kA}$

h. Kapasitas pemutus tenaga PMT sisi $150 \mathrm{kV}$ pada bay (baris) trafo daya 4 sebesar 1.024 $\mathrm{kA}$ dengan pemilihan rating PMT yang tersedia dipasaran sebesar $20 \mathrm{kA}$

i. Kapasitas pemutus tenaga PMT sisi $150 \mathrm{kV}$ pada bay (baris) penghantar transmisi line Kemang 1 dan 2 sebesar 3.915 kA dengan pemilihan rating PMT yang tersedia dipasaran sebesar $20 \mathrm{kA}$

j. Kapasitas pemutus tenaga PMT sisi $150 \mathrm{kV}$ pada bay (baris) penghantar transmisi line Pondok Indah 1 dan 2 sebesar 3.915 kA dengan pemilihan rating PMT yang tersedia dipasaran sebesar $20 \mathrm{kA}$

k. Kapasitas pemutus tenaga PMT sisi $150 \mathrm{kV}$ pada bay (baris) penghantar transmisi line Petukangan 1 dan 2 sebesar $3.536 \mathrm{kA}$ dengan pemilihan rating PMT yang tersedia dipasaran sebesar $20 \mathrm{kA}$

3. Kapasitas pemutus tenaga PMT sisi $150 \mathrm{kV}$ pada bay (baris) penghantar transmisi line Serpong 1 dan 2 sebesar 3.714 kA dengan pemilihan rating PMT yang tersedia dipasaran sebesar $20 \mathrm{kA}$

4. Perbandingan rating pemutus tenaga (PMT) yang terpasang (existing) lebih besar terhadap hasil pemilihan rating pemutus tenaga (PMT) berdasarkan perhitungan manual, sehingga dapat disimpulkan bahwa pemutus tenaga PMT yang terpasang di GI Gandul sisi $150 \mathrm{kV}$ memiliki kapasitas yang masih sesuai dengan kebutuhan dan layak digunakan meskipun telah mengalami perubahan sistem jaringan tenaga listrik meliputi penambahan sumber daya yaitu IBT $4(500 / 150 \mathrm{kV})$, penambahan sistem jaringan tranmisi line GI Pondok Indah 1 dan 2 dan bertambahnya penyulang hingga kini mencapai 62 feeder.

\section{Saran}

Berdasarkan hasil penelitian yang didapat, maka peneliti memiliki saran sebagai berikut:

1. Hasil studi nilai arus hubung singkat dalam tugas akhir ini digunakan sebagai penentu kapasitas rating pemutus tenaga (PMT) dan mengevaluasi rating pemutus tenaga (PMT) 
yang terpasang (existing) pada GI Gandul sisi $150 \mathrm{kV}$. Diharapkan hasil studi arus hubung singkat dapat digunakan untuk menentukan rating peralatan proteksi lainnya.

2. Perlu dilakukan pengujian lebih detail kepada pemutus tenaga baik itu data maupun menggunakan metode yang berbeda sehingga dapat dibandingkan hasil yang didapatkan, dan akan mendapatkan keakuratan yang lebih tinggi.

\section{DAFTAR PUSTAKA}

Afandi, AN. 2005. Sistem Tenaga Listrik Operasi Sistem dan Pengendalian. Malang: Teknik Elektro Universitas Negeri Malang.

Afandi, AN. 2010. Buku Operasi Sistem Tenaga Listrik Berbasis EDSA. Yogyakarta: Gayamedia.

Buku PT. PLN (Persero), Pusat Pendidikan dan Pelatihan.

Buku PT.PLN (Persero) Analisa Sistem Tenaga Listrik APP Cawang.

Basecamp Gardu Induk Gandul, Cinere Jakarta Selatan.

Buku AST (Yusreni Warmi). (t.d) 30 September 2014.

http://www.academia.edu/6383668/Buku

AST Yusreni Warmi.

Dasman, 2016. Studi Gangguan Hubung Singkat 1 Fasa Ke Tanah pada SUTT $150 \mathrm{KV}$ (Aplikasi GI PIP-Pauh Limo). Jurnal Teknik Elektro Institut Teknologi Padang.

Hendriyadi, 2007. Perhitungan Arus Gangguan Hubung Singkat Pada Jaringan Distribusi Di Kota Pontianak. Jurnal Teknik Elektro Universitas Tanjungpura. Vol 1:1.

Ikkholis. 2013. Analisis Gangguan Hubung Singkat

(Online)

(https://ikkholis27.wordpress.com/2013/11

/12/analisis-gangguan-hubung)

Lubis, Chandra Fireral., 2017. Penentuan Kapasitas Pemutus Tenaga Sisi 20 kV Pada Gardu Induk Sei. Raya. Jurnal Teknik Elektro Universitas Tanjungpura.Vol 2:1.

Manurung. Julian Maruli Torang., 2013. Studi Pengaman Busbar 150 kV Pada Gardu Induk Siantan . Jurnal Teknik Elektro Universitas Tanjungpura. Vol 1:1.

Marsudi, Djiteng. 2005. Pembangkitan Energi Listrik. Jakarta: Erlangga.
Multa, Lesnanto., Aridani, Restu Prima., Modul Pelatihan ETAP, Yogyakarta: Universitas Gadjah Mada, 2013.

Pandjaitan, Bonar. 2012. Praktik-praktik Proteksi Sistem Tenaga Listrik. Yogyakarta: Andi Offset.

Posundu, Filia Majesty., Patras, Lily S., Tuegeh, Maickel., 2013.Penentuan Kapasitas CB Dengan Analisa Hubung Singkat Pada Jaringan $70 k \mathrm{~V}$ Sistem Minahasa. Jurnal Teknik Elektro dan Komputer. Vol $2: 2$. 